\title{
SH1 - Comunidades de Población en Resistencia: modelo de organización social a seguir ${ }^{1}$
}

\author{
Cindy López \\ Universidad de San Carlos de Guatemala
}

\section{Resumen}

- 1 artículo se basa en un estudio presentado por el autor en el curso de este año a la Dirección General de In-

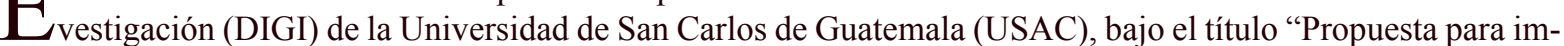
pulsar la conservación de suelos agrícolas y rehabilitación de tierras degradadas en la República de Guatemala". La metodología incluyó una revisión documental y entrevistas con expertos en el tema; los resultados indican que actualmente la conservación de suelos no ocupa ninguna prioridad dentro de las estrategias de producción agrícola y de protección de los recursos naturales. La erosión hídrica es la principal forma de degradación de los suelos agrícolas; el promedio nacional de pérdida de suelos alcanza 149 millones de toneladas anuales, que representa un valor monetario aproximado de 727 millones de quetzales. Existe debilidad institucional y política para hacer frente a la degradación de los suelos y por esta razón en este estudio, se propone un marco de política nacional cuyos ejes principales se enfocan a la promoción de diversos métodos de conservación de suelos y rehabilitación de tierras degradadas. Se recomienda además, un marco de acciones para fortalecer la capacitación y las instituciones de gobierno y de la sociedad civil para la conservación de los suelos agrícolas.

Palabras clave: Organización social, desarrollo social, democracia de base, comunidad.

\section{Abstract}

The recent history of Guatemala evidence that the development model implemented with the "democracy" 1 has not succeeded in eliminating poverty. The conditions that caused the Internal Armed Conflict are still present. It is necessary to investigate to propose alternatives to try to reduce this situation. Therefore the concern in knowing the organization of the CPR to know if their structure has represented a benefit equally for all its members, promoting a communitarian dynamic that enable a paradigm of harmonious development. As well as the interest to determine whether the organization of CPR can be replicated today; that is why it is necessary to study in detail their organization over the years of resistance and how after their resettlement have managed to maintain it. To know if this model of organization is genuine, is going to be compared with an imposed model based on authoritarian policies, such as the Development Poles. A preliminary conclusion is that the consensus decision-making (pure/direct democracy), makes possible a deeper and more harmonious development.

Keywords: Social organization, social development, pure/direct democracy, community.

1 El presente documento es un fragmento del informe de investigación que la autora está elaborando como requisito de graduación de la Maestría en formulación y evaluación de proyectos para el desarrollo social, de la Escuela de Trabajo Social de la Universidad de San Carlos de Guatemala. 